\title{
Review \\ Plant Copper Amine Oxidases: Key Players in Hormone Signaling Leading to Stress-Induced Phenotypic Plasticity
}

\author{
Ilaria Fraudentali ${ }^{1}$, Renato A. Rodrigues-Pousada ${ }^{2}$, Riccardo Angelini ${ }^{1,3}{ }^{\mathbb{D}}$, Sandip A. Ghuge ${ }^{4, *}$ \\ and Alessandra Cona $1,3, *$ (D) \\ 1 Department of Science, University “Roma Tre”, 00146 Rome, Italy; ilaria.fraudentali@uniroma3.it (I.F.); \\ riccardo.angelini@uniroma3.it (R.A.) \\ 2 Department of Life, Health and Environmental Sciences, University of L'Aquila, 67100 L'Aquila, Italy; \\ renatoalberto.rodriguespousada@univaq.it \\ 3 Interuniversity Consortium National Institute of Biostructures and Biosystems (INBB), 00136 Rome, Italy \\ 4 The Volcani Center, ARO, Institute of Plant Sciences, Bet Dagan 50250, Israel \\ * Correspondence: sandip.ghuge.biotech@gmail.com (S.A.G.); alessandra.cona@uniroma3.it (A.C.); \\ Tel.: +39-065-733-6360 (A.C.)
}

check for

updates

Citation: Fraudentali, I.;

Rodrigues-Pousada, R.A.; Angelini,

R.; Ghuge, S.A.; Cona, A. Plant

Copper Amine Oxidases: Key Players

in Hormone Signaling Leading to

Stress-Induced Phenotypic Plasticity.

Int. J. Mol. Sci. 2021, 22, 5136.

https://doi.org/10.3390/ijms22105136

Academic Editors: Mohammad Golam Mostofa and Lam-Son Phan Tran

Received: 30 March 2021

Accepted: 7 May 2021

Published: 12 May 2021

Publisher's Note: MDPI stays neutral with regard to jurisdictional claims in published maps and institutional affiliations.

Copyright: (c) 2021 by the authors. Licensee MDPI, Basel, Switzerland. This article is an open access article distributed under the terms and conditions of the Creative Commons Attribution (CC BY) license (https:// creativecommons.org/licenses/by/ $4.0 /)$.

\begin{abstract}
Polyamines are ubiquitous, low-molecular-weight aliphatic compounds, present in living organisms and essential for cell growth and differentiation. Copper amine oxidases (CuAOs) oxidize polyamines to aminoaldehydes releasing ammonium and hydrogen peroxide, which participates in the complex network of reactive oxygen species acting as signaling molecules involved in responses to biotic and abiotic stresses. CuAOs have been identified and characterized in different plant species, but the most extensive study on a CUAO gene family has been carried out in Arabidopsis thaliana. Growing attention has been devoted in the last years to the investigation of the CuAO expression pattern during development and in response to an array of stress and stress-related hormones, events in which recent studies have highlighted CuAOs to play a key role by modulation of a multilevel phenotypic plasticity expression. In this review, the attention will be focused on the involvement of different AtCuAOs in the IAA/JA/ABA signal transduction pathways which mediate stress-induced phenotypic plasticity events.
\end{abstract}

Keywords: abscisic acid; auxin; copper amine oxidases; hormones; hydrogen peroxide; jasmonic acid; polyamines; root plasticity; wounding

\section{Introduction: The Plant Amine Oxidase Network}

Biogenic amines are low molecular weight organic nitrogen compounds, which are present in living cells and include compounds with different structures ranging from aliphatic and aromatic monoamines to diamines and higher polyamines. The diamines putrescine (Put) and cadaverine (Cad), and the polyamines spermidine (Spd) and spermine (Spm) (all together referred as PAs), are aliphatic polycations characterized by the presence of two or more amine functional groups, involved in a lot of physiological events and defense responses in plants [1-7]. Amine oxidases (AOs) belong to a heterogeneous class of enzymes including copper amine oxidases ( $\mathrm{CuAOs)} \mathrm{and} \mathrm{flavin-containing} \mathrm{polyamine}$ oxidases (PAOs) and are part of the complex enzyme network catalyzing the oxidative de-amination of PAs to aminoaldehydes. An amine moiety, ammonium and the biologically active hydrogen peroxide $\left(\mathrm{H}_{2} \mathrm{O}_{2}\right)$, are co-products in the $\mathrm{AO}$ oxidation reactions. Plant PAOs oxidize PAs at the secondary amino groups by either a terminal catabolism or interconversion pathway with reaction products depending on both catalytic mechanism and specific substrates. On the other hand, $\mathrm{CuAOs}$ are exclusively involved in the terminal catabolism of PAs, oxidizing PAs and monoamines at the terminal amine group with the production of ammonium, the substrate-corresponding aminoaldehyde and $\mathrm{H}_{2} \mathrm{O}_{2}$ [8-15]. 
2. The Amine Oxidase $C u A O$ Gene Family: Subcellular Localization and Biochemical Properties of CuAOs from Different Plant Species

CuAOs are homodimeric enzymes consisting of a 70-90 kD subunits, each containing a copper ion and a 2,4,5-trihydroxyphenylalanine quinone (TPQ) cofactor generated by a post-translational autocatalytic modification of an active site tyrosine residue $[10,13]$.

CuAOs have been identified and characterized in different plant species [8-13]. The most extensive study on a CuAO gene family has been carried out in Arabidopsis thaliana (Arabidopsis), in which ten different genes encoding $\mathrm{CuAOs}$ have been identified, although only eight of them encode for putative functional CuAOs: AtCuAO $\alpha 1$

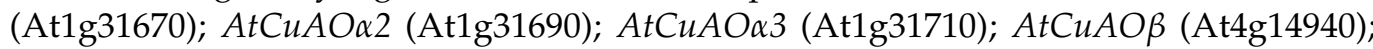

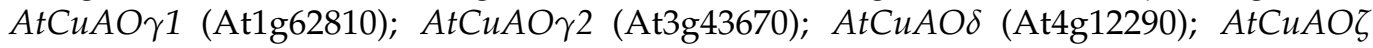

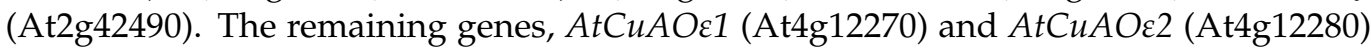
are located upstream of $A t C u A O \delta$ on chromosome 4, and are possibly generated by an $A t C u A O \delta$ duplication event, followed by an insertion of the transposable element At4g12275 [10,16-21]. Recently, eight putative CuAO genes (CsCuAO1-CsCuAO8), distributed on three chromosomes, were identified in Citrus sinensis Osbeck genome [22] and a full-length Camellia sinensis $\mathrm{CuAO}$ gene $(\mathrm{CsCuAO})$ was isolated and cloned from a drought tolerant tea cultivar [23].

Genetic, biochemical and histological approaches highlight that most of $\mathrm{CuAOs}$ localize in the apoplast (AtCuAO $\beta$, AtCuAO $\gamma 1, \mathrm{MdAO} 1, \mathrm{PSAO}, \mathrm{ELAO}, \mathrm{LSAO}, \mathrm{CaCuAO}, \mathrm{VfCuAO}$ and NtCuAO [13,14,17,18,24-29] or peroxisome (AtCuAO $\alpha 2$, AtCuAO $\alpha 3, \mathrm{AtCuAO}$, MdAO1, NtDAO1 and NtMPO1 $[17,19,25,30]$ with the exception of AtCuAO $\delta$ that has been found to localize in the vacuole [31].

Although CuAOs show a broad variety of substrate specificity, some of them also oxidizing monoamines, CuAOs explored to date primarily oxidize the diamines Put and Cad, while Spd and especially Spm oxidation by most of them is less efficient, with the exception of AtCuAO $\gamma 1$ and $\mathrm{AtCuAO} \alpha 3$, that show an affinity for Spd comparable to that for Put $[10,17]$. In details, the cell-wall resident CuAOs from Pisum sativum (PSAO [11,32]) and Lens culinaris (LSAO $[11,28,33]$ ) showed a Put/Spd/Spm oxidation ratio of respectively 100:35:0.3 [11] and 100:42:20 [11] while the peroxisomal Malus domestica CuAO1 (MdAO1) do not oxidize Spd and Spm, showing activity only with the diamines Put, Cad and 1,3-diaminopropane (Dap) [25]. It is noteworthy that the extracellular Malus domestica $\mathrm{CuAO} 2$ (MdAO2) exclusively oxidize aliphatic and aromatic monoamines, among which 2-phenylethylamine is oxidatively deaminated to phenylacetaldehyde that in fruits may be converted to 2-phenylethanol, a volatile compound that is a major contributor to fruit flavor and flower fragrance [25]. In Nicotiana tabacum, the peroxisomal NtCuAO $\mathrm{N}$-methylputrescine oxidase 1 (NtMPO1) that is involved in nicotine biosynthesis, preferentially oxidize $N$-methylputrescine $[19,34]$, while Put oxidation is carried out both in the cell wall and in peroxisome by respectively an apoplastic $\mathrm{NtCuAO}$ activity [35] and diamine oxidase 1 (NtDAO1) [19]. The aminoaldehyde produced by the $\mathrm{CuAO}$-driven oxidation of Put is 4-aminobutanal [10], which spontaneously cyclizes to $\Delta^{1}$-pyrroline that is further converted to $\gamma$-aminobutyric acid (GABA) by a NAD-dependent aminoaldehyde dehydrogenase. GABA in turn, undergo transamination and oxidation to form succinic acid, which is assimilated into the Krebs cycle, ensuring carbon and nitrogen re-assimilation from Put $[11,36,37]$. The aminoaldehydes produced by the $\mathrm{CuAO}$-driven oxidation of $\mathrm{Cad}$ and Spd are 5-aminovaleraldheyde and 3-aminopropyl-4-aminobutyraldehyde, spontaneously cyclizing to $\Delta^{1}$-piperideine or 1,5-diazabicyclononane, respectively [14].

\section{CuAOs in Development and Hormonal Signaling Pathways: Analysis of Tissues Specific- and Hormone/Stress-Modulated-CuAO Expression Profiles}

Growing attention has been devoted in the last years to the investigation of the $\mathrm{CuAO}$ expression pattern during development and in response to an array of stress and stressrelated hormones. To this purpose, tissue-specific expression analysis and quantitative expression studies have been performed exploiting AtCuAOs promoter::green fluorescent protein- $\beta$-glucuronidase fusion (GFP-GUS) transformed Arabidopsis plants and RT-qPCR ap- 
proaches. In Arabidopsis seedlings at early developmental stage, $A t C u A O$ promoter activity was revealed in tissues involved in water supply and/or water loss such as hydathodes, stomata and vascular tissues as well as in growing tissues responsible for organ development and growth rate modulation. Expression has been found in hydathodes of expanding

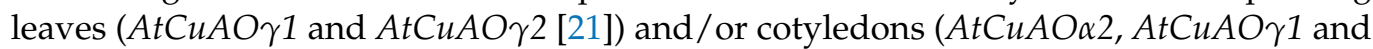
$A t C u A O \gamma 2$ [21]); in stomata of cotyledons (AtCuAOß [38]; $A t C u A O \zeta$ [20]) and flowers (AtCuAO $\beta$ [38]) as well as in vascular tissues of (i) cotyledons, expanding leaves and hypocotyl (AtCuAO 1 [ 21]); (ii) hypocotyl, hypocotyl/root junction and root mature zone

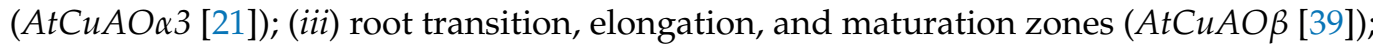

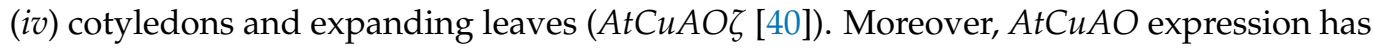

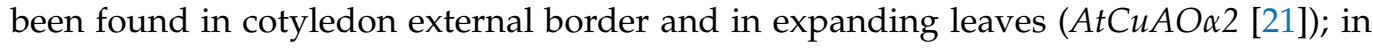

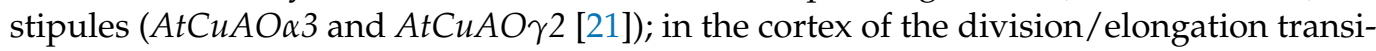

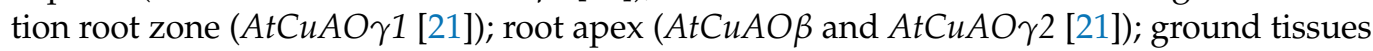

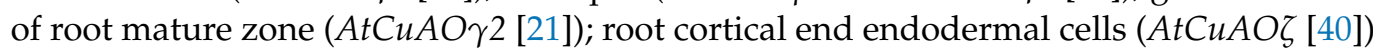
(Figure 1).

Analysis of PA- modulated expression profiles of $A t C u A O s$ reveals that most of the characterized $A t C u A O s$ are induced by Put (AtCuAO $\alpha 2 / \alpha 3 / \gamma 1 / \gamma 2)$ [21] (Figure 1). On the contrary, expression of $A t C u A O s$ may be either induced $(A t C u A O \alpha 2 / \alpha 3)$ or inhibited

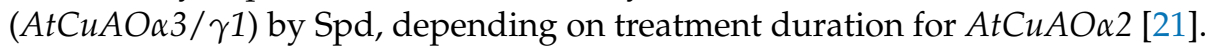

Analysis of hormone- and stress-modulated expression profiles of $A t C u A O s$ reveals that most of the characterized $A t C u A O s$ are modulated by stress and/or by stress-related hormones. As shown in Figure 1, AtCuAO $\alpha 2 / \alpha 3 / \gamma 1 / \gamma 2 / \beta$ are all induced by wounding and methyl-jasmonate (MeJA) $[17,21,38,39]$ with the exception of $A t C u A O \gamma 2$ that is inhibited by MeJA treatment [21], four of them by drought and indole-3-acetic acid (IAA) (AtCuAO $2 / \alpha 3 / \gamma 1 / \gamma 2[21,40]$ ), while $A t C u A O \beta$ is not responsive to IAA [41]. Interestingly, after both treatments a tardive repression occurs after the early reported gene induction

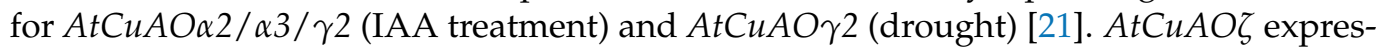
sion is also induced by IAA and MeJA [17,40], while it is repressed by wounding [17]. Moreover, abscisic acid (ABA), flagellin and salicylic acid (SA) are all active in inducing both $A t C u A O \gamma 1$ and $A t C u A O \zeta$ expression [17,20], while ABA was reported to induce AtCuAO $\delta$ [42]. However, AtCuAO $\alpha 2 / \alpha 3 / \gamma 2$ are repressed by both ABA and SA, while $A t C u A O \gamma 1$ shows an early inhibition of gene expression preceding the SA reported induction [21]. Data about wounding and MeJA effect on AtCuAO expression, are in line with previous evidences reporting the induction of $\mathrm{CuAO}$ expression in Hordeum vulgare [43] and Nicotiana tabacum [44] upon MeJA treatment as well as in Cicer arietinum upon wounding and jasmonic acid (JA) treatment [45]. 


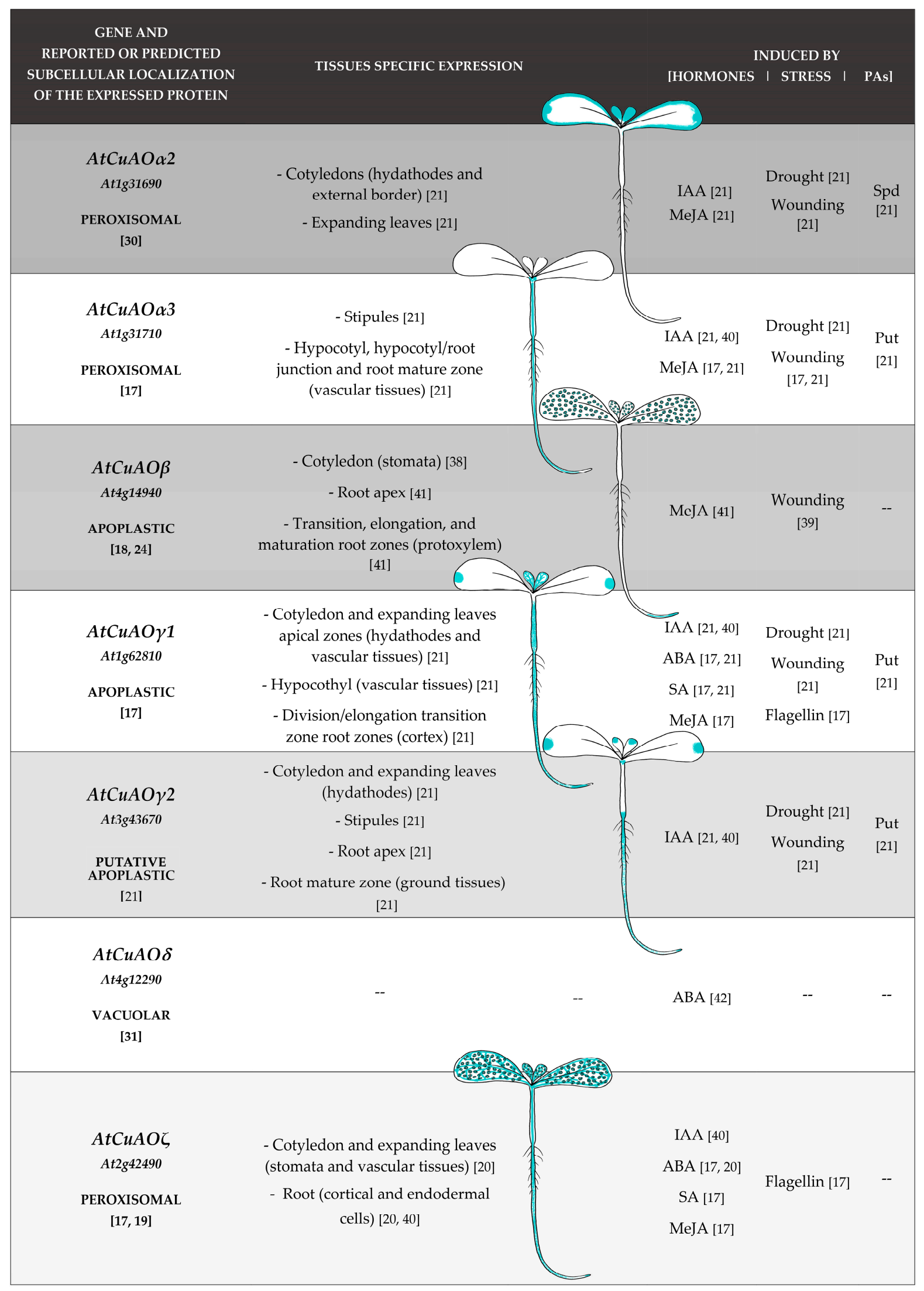

Figure 1. Schematic representation of transcriptional activity of $C u A O$ promoters in organs/tissues of Arabidopsis plantlets and induction by stress, stress-related hormones and PAs. 


\section{CuAOs as PA Level Modulators and Sources of Reactive Compounds in the Cytoplasm and Cell Wall}

Many studies in different plant species highlight the contribution of AOs to plant development and defence responses by a dual role, as PA level modulators and bioactive compound sources, that is $\mathrm{H}_{2} \mathrm{O}_{2}$ and aminoaldehydes. Considering that both PAs and $\mathrm{H}_{2} \mathrm{O}_{2}$ may trigger signal transduction pathways leading to phenotypic plasticity or defense responses during developmentally controlled or stress-induced events, AO may represent a checkpoint in the balance of the PAs $/ \mathrm{H}_{2} \mathrm{O}_{2}$ ratio, supposed to be responsible for important physiological events such as cell fate determination in developmental, or hypersensitive (HR), cell death [46].

PA-derived aminoaldehydes represent important metabolites involved in carbon and nitrogen recycling and/or redirecting to different metabolic pathways, as for instance Put-/methylPut-derived aminoaldehydes, respectively precursors of GABA and alkaloids, which have been shown to rapidly accumulate in stressed plants. In this regard, $\mathrm{CuAO}$ activity has been suggested to contribute via PA-derived aminoaldehyde (i) in salt stress-induced GABA accumulation in Glycine max [47], (ii) in wound-induced GABA accumulation in Pisum sativum [37], (iii) in MeJA-induced nicotine biosynthesis in Nicotiana tabacum [19] and (iv) to the production of 2-phenylethanol, responsible for fruit flavour and flower fragrance in Malus domestica [25].

$\mathrm{CuAOs}$ also participate in signalling processes via regulation of nitric oxide (NO) production. In this regard, noteworthy is the involvement of apoplastic AtCuAO $\gamma 1$ in $\mathrm{ABA}-$ mediated stress responses via $\mathrm{ABA}$-induced $\mathrm{NO}$ production [48], $\mathrm{CuAO}$ activityderived $\mathrm{H}_{2} \mathrm{O}_{2}$ possibly acting as an upstream trigger for $\mathrm{NO}$ biosynthesis [48]. Moreover, the peroxisomal AtCuAO $\alpha 2$ has been proposed to have a role in arginine-dependent NO synthesis by altering arginine availability through modulation of arginase activity [16,49].

PA homeostasis may assume a key role in rapidly proliferating and fast growing tissues involved in organ formation, in which regulation of PA cellular content is implicated in cell cycle regulation. CuAOs play a role at the early cell division phase of tuber growth in Helianthus tuberosus [50], in cell growth cycle at the onset of cell division [51] and in cell cycle-endocycle progression in vascular tissues in Nicotiana tabacum [52]. The occurrence of AtCuAOs in meristematic zones, where an auxin maximum is positioned, has been observed [21]. Recently, PA homeostasis accomplished by AtCuAO $\mathrm{\delta}$ has been revealed to take part in GA-mediated control of germination, leaf development and flowering time by a reduction in GA biosynthesis. Concerning this, the change in auxin levels may represent a possible causal link between the increase in Put level in Atcuao $\delta$ mutants and the reduction in expression of GA biosynthesis genes [53]. Likewise, perturbation of CuAO/PAO-mediated maintenance of PA homeostasis, by unbalancing PA biosynthesis/oxidation rates, may contribute to PA accumulation under osmotic stress in Vitis vinifera cv. Chardonnay, during which impaired defense responses against pathogens and reduced ABA biosynthesis have also been observed [54]. This evidence emphasizes the role of PA oxidation, via either PA homeostasis or $\mathrm{H}_{2} \mathrm{O}_{2}$ delivering, in osmotic stress signaling and defense responses upon biotic stress and suggests a link between PA oxidation and ABA biosynthesis under osmotic stress [54].

In this regard, a central role has been ascribed to $\mathrm{H}_{2} \mathrm{O}_{2}$ derived from PA oxidation, especially regarding the cell wall-resident $\mathrm{AOs}$ whose activity is restricted by the limited amounts of extracellular PAs and depends on developmentally regulated or stress-induced PA secretion $[35,46,55,56]$. The absence/low amount of PAs in the apoplast, along with the occurrence of high $\mathrm{AO}$ levels in the apoplast also in non-stressing environments [56], suggest a role of wall-secreted PAs mainly as $\mathrm{H}_{2} \mathrm{O}_{2}$ sources by their AO-driven oxidation rather than signalling compounds themselves. In the cell wall, $\mathrm{H}_{2} \mathrm{O}_{2}$-derived from CuAOmediated PA oxidation may represent a significant part of the ROS apoplastic network and behaves as a multifunctional compound: (i) triggering intracellular signal transduction pathways leading to increased expression of defence genes and hypersensitive (HR)-cell death in infected area; (ii) playing a role in defense against plant pathogens by a direct 
anti-microbial activity and (iii) participating as co-substrate in peroxidase-mediated lignin biosynthesis and cross-linking of cell wall polysaccharides and proteins in the modulation of cell wall expansion and its maturation after cessation of growth [11-13]. Accordingly, $\mathrm{CuAO}$-driven $\mathrm{H}_{2} \mathrm{O}_{2}$ production in the apoplast has been implicated in cell wall stiffening events responsible for developmental cell wall maturation in Pisum sativum [26], Lens culinaris [26], Cicer arietinum [26,45] and Nicotiana tabacum [52], lignin deposition in differentiating protoxylem elements in Arabidopsis [18,41] as well as during defence responses to pathogen attack and wound healing in Cicer arietinum [45]. The apoplastic $\mathrm{NtCuAO}$-driven $\mathrm{H}_{2} \mathrm{O}_{2}$ production has been involved in early root xylem differentiation in Nicotiana tabacum plants over-expressing a fungal endopolygalacturonase, which are characterized by constitutively activated defense responses [57]. Similarly, the apoplastic AtCuAO $\beta$-driven $\mathrm{H}_{2} \mathrm{O}_{2}$ production has been shown to be a key factor in leaf wounding-induced JA-mediated early root protoxylem differentiation in Arabidopsis [39,41]. Noteworthy, $\mathrm{H}_{2} \mathrm{O}_{2}$ derived from the apoplastic VfCuAO-mediated oxidation of Put has been reported to be involved in ABA-induced and darkness-induced stomatal closure in Vicia faba through a mechanism in-

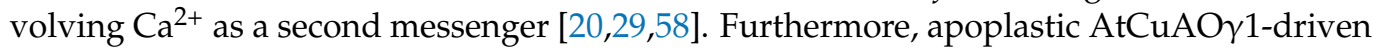
Put oxidation elicits ROS-dependent SA-signaled pathways leading to activation of plant defenses in Arabidopsis [59].

Concerning intracellular $\mathrm{CuAO}$-derived $\mathrm{H}_{2} \mathrm{O}_{2}$, the peroxisomal AtCuAO$\zeta$ [20] and the vacuolar AtCuAOs [42] have been reported to be involved in ABA-induced stomatal closure through $\mathrm{H}_{2} \mathrm{O}_{2}$ production.

Overall, recent literature highlight $\mathrm{CuAOs}$ to play a key role in ontogenetic and environment-regulated developmental events as well as in defence responses by modulation of a multilevel phenotypic plasticity expression, ranging from fast stomatal closure or metabolic plasticity to produce stress-related compounds, up to long-term phenotypic acclimation including organ growth rate, photoperiod/seasonal-dependent events and morpho-anatomical traits. Hereafter, the attention will be focused on the role of the different AtCuAOs in stress-induced phenotypic plasticity as components of the IAA/JA/ABA signal transduction pathways (Table 1).

Table 1. Subcellular localization and physiological functions of plant CuAOs.

\begin{tabular}{|c|c|c|}
\hline CuAOs/Plant Sources & Subcellular Localization & Reported Physiological Functions \\
\hline $\begin{array}{l}\text { AtCuAO } \beta \\
\text { Arabidopsis }\end{array}$ & $\begin{array}{l}\text { Apoplast } \\
{[18,24]}\end{array}$ & $\begin{array}{l}\text { - } \quad \text { MeJA-induced vascular development via PA-derived } \mathrm{H}_{2} \mathrm{O}_{2}[18] \\
\text { Leaf wounding-induced vascular development via PA-derived } \\
\mathrm{H}_{2} \mathrm{O}_{2}[39]\end{array}$ \\
\hline $\begin{array}{l}\text { AtCuAO } \alpha 2 \\
\text { Arabidopsis }\end{array}$ & $\begin{array}{l}\text { Peroxisome } \\
{[30]}\end{array}$ & $\begin{array}{l}\text { - Salt stress/elicitor-induced NO production affecting primary root } \\
\text { growth via arginase activity down-regulation [16] }\end{array}$ \\
\hline $\begin{array}{l}\text { AtCuAO } \gamma 1 \\
\text { Arabidopsis }\end{array}$ & $\begin{array}{l}\text { Apoplast } \\
\text { [17] }\end{array}$ & $\begin{array}{l}\text { - } \quad \text { ABA-mediated inhibition of germination and root growth via } \mathrm{NO} \\
\text { induced by PA-derived } \mathrm{H}_{2} \mathrm{O}_{2}[48] \\
\text { - } \quad \text { SA-signaled pathways leading to activation of plant defenses } \\
\text { against pathogens via PA-derived } \mathrm{H}_{2} \mathrm{O}_{2} \text { [59] }\end{array}$ \\
\hline $\begin{array}{l}\text { AtCuAOs } \\
\text { Arabidopsis }\end{array}$ & $\begin{array}{l}\text { Vacuole } \\
\text { [31] }\end{array}$ & $\begin{array}{l}\text { - } \quad \text { ABA-mediated stomatal closure via PA-derived } \mathrm{H}_{2} \mathrm{O}_{2} \text { [42] } \\
\text { - } \quad \text { GA-mediated development (germination, leaf development and } \\
\text { flowering time) via PA homeostasis [53] }\end{array}$ \\
\hline $\begin{array}{l}\text { AtCuAO } \\
\text { Arabidopsis }\end{array}$ & $\begin{array}{l}\text { Peroxisome } \\
{[17,19]}\end{array}$ & $\begin{array}{ll}\text { - } & \text { ABA-induced stomatal closure via PA-derived } \mathrm{H}_{2} \mathrm{O}_{2}[20] \\
\text { - } & \text { IAA-induced lateral root development via PA-derived } \mathrm{H}_{2} \mathrm{O}_{2} \text { [40] }\end{array}$ \\
\hline $\begin{array}{c}\text { MdAO1 } \\
\text { Malus domestica }\end{array}$ & $\begin{array}{l}\text { Peroxisome } \\
\quad[25]\end{array}$ & - $\quad$ GABA production via PA-derived aminoaldehyde [25] \\
\hline $\begin{array}{c}\text { MdAO2 } \\
\text { Malus domestica }\end{array}$ & $\begin{array}{l}\text { Apoplast } \\
\text { [25] }\end{array}$ & $\begin{array}{l}\text { - Deamination of 2-phenylethylamine for 2-phenylethanol } \\
\text { production (a contributor to fruit flavour and flower fragrance) [25] }\end{array}$ \\
\hline $\begin{array}{c}\text { PSAO } \\
\text { Pisum sativum }\end{array}$ & $\begin{array}{l}\text { Apoplast } \\
{[14,26]}\end{array}$ & 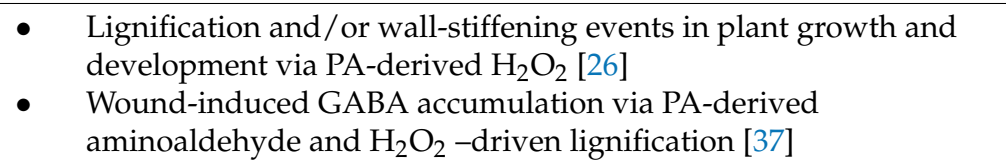 \\
\hline
\end{tabular}


Table 1. Cont.

\begin{tabular}{|c|c|c|}
\hline CuAOs/Plant Sources & Subcellular Localization & Reported Physiological Functions \\
\hline $\begin{array}{c}\text { ELAO } \\
\text { Euphorbia characias }\end{array}$ & $\begin{array}{l}\text { Apoplast } \\
\text { [27] }\end{array}$ & - \\
\hline $\begin{array}{c}\text { LSAO } \\
\text { Lens culinaris }\end{array}$ & $\begin{array}{l}\text { Apoplast } \\
{[14,26,28]}\end{array}$ & $\begin{array}{l}\text { - Lignification and/or wall-stiffening events in plant growth and } \\
\text { development via PA-derived } \mathrm{H}_{2} \mathrm{O}_{2} \text { [26] }\end{array}$ \\
\hline $\begin{array}{l}\text { CaCuAO } \\
\text { Cicer arietinum }\end{array}$ & $\begin{array}{l}\text { Apoplast } \\
{[14,26]}\end{array}$ & $\begin{array}{l}\text { - Lignification and/or wall-stiffening events in plant growth and } \\
\text { development via PA-derived } \mathrm{H}_{2} \mathrm{O}_{2} \text { [26] } \\
\text { - Wound healing and defense responses to pathogen via PA-derived } \\
\mathrm{H}_{2} \mathrm{O}_{2} \text { [45] }\end{array}$ \\
\hline $\begin{array}{l}\text { GmCuAO } \\
\text { Glycine max }\end{array}$ & - & $\begin{array}{l}\text { - } \quad \text { Salt stress-induced GABA accumulation via PA-derived } \\
\text { aminoaldehyde [47] }\end{array}$ \\
\hline $\begin{array}{c}\text { HvCuAO } \\
\text { Hordeum vulgare }\end{array}$ & - & $\begin{array}{l}\text { - } \quad \text { MeJA-mediated protection against powdery mildew fungus } \\
\text { Blumeria graminis infection [43] }\end{array}$ \\
\hline $\begin{array}{c}\mathrm{HtCuAO} \\
\text { Helianthus tuberosus }\end{array}$ & - & $\begin{array}{l}\text { - Role in development at the early cell division phase of tuber growth } \\
\text { and during the cell enlargement [50] }\end{array}$ \\
\hline $\begin{array}{l}\text { VfCuAO } \\
\text { Viciafaba }\end{array}$ & $\begin{array}{l}\text { Apoplast } \\
\text { [29] }\end{array}$ & $\begin{array}{ll}\text { - } & \text { ABA-induced stomatal closure via PA-derived } \mathrm{H}_{2} \mathrm{O}_{2}[20,29] \\
\text { - } & \text { Dark-induced stomatal closure via PA-derived } \mathrm{H}_{2} \mathrm{O}_{2}[58]\end{array}$ \\
\hline $\begin{array}{l}\mathrm{NtCuAO} \\
\text { Nicotiana tabacum }\end{array}$ & - & $\begin{array}{l}\text { - } \quad \text { Cell growth cycle at the onset of cell division via PA } \\
\text { homeostasis [51] } \\
\text { - } \quad \text { Cell cycle-endocycle progression in vascular tissues [52] } \\
\text { - } \quad \text { Defense response to pathogen via apoplastic PA-derived } \mathrm{H}_{2} \mathrm{O}_{2} \text { [35] } \\
\text { Early root xylem differentiation via apoplastic PA-derived } \\
\mathrm{H}_{2} \mathrm{O}_{2} \text { [57] }\end{array}$ \\
\hline $\begin{array}{c}\text { NtDAO1 } \\
\text { Nicotiana tabacum }\end{array}$ & $\begin{array}{l}\text { Peroxisome } \\
\text { [19] }\end{array}$ & - $\quad$ PA (Put) catabolism [19] \\
\hline $\begin{array}{c}\text { NtMPO1 } \\
\text { Nicotiana tabacum }\end{array}$ & $\begin{array}{l}\text { Peroxisome } \\
\quad[19]\end{array}$ & $\begin{array}{l}\text { - } \quad N \text {-methylated Put as substrate in MeJA-induced alkaloid } \\
\text { biosynthesis }[19,34]\end{array}$ \\
\hline
\end{tabular}

\section{AOs Play a Role in Xylem Phenotypic Plasticity}

It is known that xylem vessels differentiation depends on coordinated events of cell wall lignification and developmental $\mathrm{PCD}$, both requiring $\mathrm{H}_{2} \mathrm{O}_{2}$. In this regard, it has been suggested that the $\mathrm{H}_{2} \mathrm{O}_{2}$ produced by cell-wall localized AOs may play a key role in the maturation of xylem cells by triggering the peroxidase-driven polymerization of monolignols and by signaling developmental PCD in differentiating xylem precursors, depending on developmentally regulated or stress-induced PA secretion into the apoplast $[13,41,57,60,61]$. In physiological conditions, xylem differentiation $[62,63]$ and root meristem size $[64,65]$ are respectively controlled by the auxin/cytokinin/Thermo-Spm and auxin/cytokinin loops [62,63], which integrate the vascular patterning in the root developmental program, strictly coordinating root length, meristem size and protoxylem element position [66]. However, under stress conditions this correlation may be disrupted, and meristem size and protoxylem position may vary independently of each other [66]. Intriguingly, ROS, especially the $\mathrm{O}_{2}{ }^{-} / \mathrm{H}_{2} \mathrm{O}_{2}$ ratio, can also affect root meristem size and transition from cell proliferation to differentiation independently of the auxin/cytokinin pathway $[67,68]$. In this regard, the ROS-dependent signaling pathway responsible for meristem size positioning involves UPBEAT transcription factors repressing peroxidase expression in the elongation zone [67]. Likewise, under stress conditions, the dominance of auxin/cytokinin/Thermo-Spm loop in xylem differentiation could be overwhelmed by different signals and xylem differentiation has been suggested to be triggered by stressinduced AO-driven $\mathrm{H}_{2} \mathrm{O}_{2}$ production $[39,41,57,60,69]$. On the basis of these results, it is tempting to hypothesize that root xylem differentiation in normal conditions is under the auxin/cytokinin/T-Spm loop dominance, as well specific modulation of peroxidases, or other oxidases such as AOs, involved in ROS homeostasis, that regulate the timing 
of the differentiation events and the correct position of the xylem elements with respect to the apex. However, under stress conditions, such as those simulated by PA treatment [60] and endopolygalacturonase over-expression [57], as well as those mediated by JA [41], an increased stress-induced AO expression and/or PA secretion result in enhanced production of $\mathrm{H}_{2} \mathrm{O}_{2}$ that may become the prevalent signal leading to early protoxylem precursors differentiation.

\section{Expression of IAA- and Stress-Inducible AtCuAOs in Free-Auxin Maximum Zones Suggest an Role in Both Developmentally Regulated and Stress-Induced Xylem Differentiation in the Leaf and in the Root}

Leaf vascular differentiation occurs under hormonal control at early stages of primordium development. To explain vascular patterning in dicotyledonous leaves, the leaf venation hypothesis has been proposed by which an auxin gradient arising from the freeauxin maximum zones induces xylem vessels differentiation, depending on the distance between the site of hormone synthesis and the location of the differentiating vascular tissues [70-72]. Fast-growing regions are the major locations of auxin production, especially hydathodes, which develop in the leaf tip and later in the lobes and represent primary sites of auxin synthesis during leaf morphogenesis, and stipules near the shoot apex [72]. During leaf primordium development, free-auxin maximum zones gradually shift basipetally along the margins up to the central leaf region.

Noteworthy, it has been reported that expression of some members of the $A t C u A O$ family is IAA-inducible (AtCuAO $\alpha 2 / \alpha 3 / \gamma 1 / \gamma 2 / \zeta)$ and show a tissue specific expression in zones where a free-auxin maximum has been reported $[21,72,73]$. Hereafter, the overlap between the expression of members of the $A t C u A O$ family and free-auxin maximum zones is summarized (Figure 2). AtCuAO $\alpha 3$ is expressed in stipules [21]; $\alpha 2$ and $\gamma 1$ in leaf primordium tips [21]; $\alpha 2, \gamma 1$ and $\gamma 2$ in hydathodes [21]; $\alpha 2$ in leaf margins of expanding leaves or cotyledons [21]; $\gamma 2$ in the root apex [21] and $A t C u A O \beta$ and $A t C u A O \zeta$ in stomata $[20,38]$. Considering these data, it is reasonable to hypothesize that the peroxisomal AtCuAO $\alpha 2 / \alpha 3 / \zeta$ and the apoplastic $\gamma 1 / \gamma 2$ contribute to developmentally regulated xylem differentiation in leaf $(\alpha 2 / \alpha 3 / \gamma 1 / \gamma 2 / \zeta)$ and $\operatorname{root}(\gamma 2)$, by $\mathrm{H}_{2} \mathrm{O}_{2}$ production in the apoplast and in the peroxisome and/or PA homeostasis in the peroxisome. Moreover, the evidence that the expression of IAA-inducible AtCuAO $\alpha 2 / \alpha 3 / \gamma 1 / \gamma 2 / \zeta$ are also inducible by different stress and stress-related hormones (Figures 1 and 2), allows to hypothesize that their expression in areas of free auxin production responsible for xylem differentiation patterning, could be also suitable for xylem adaptive plasticity under stress conditions in the leaf as well in the root, independently from the auxin/cytokinin loop, such as during drought stress to enhance water uptake by improving root hydraulic conductivity. 


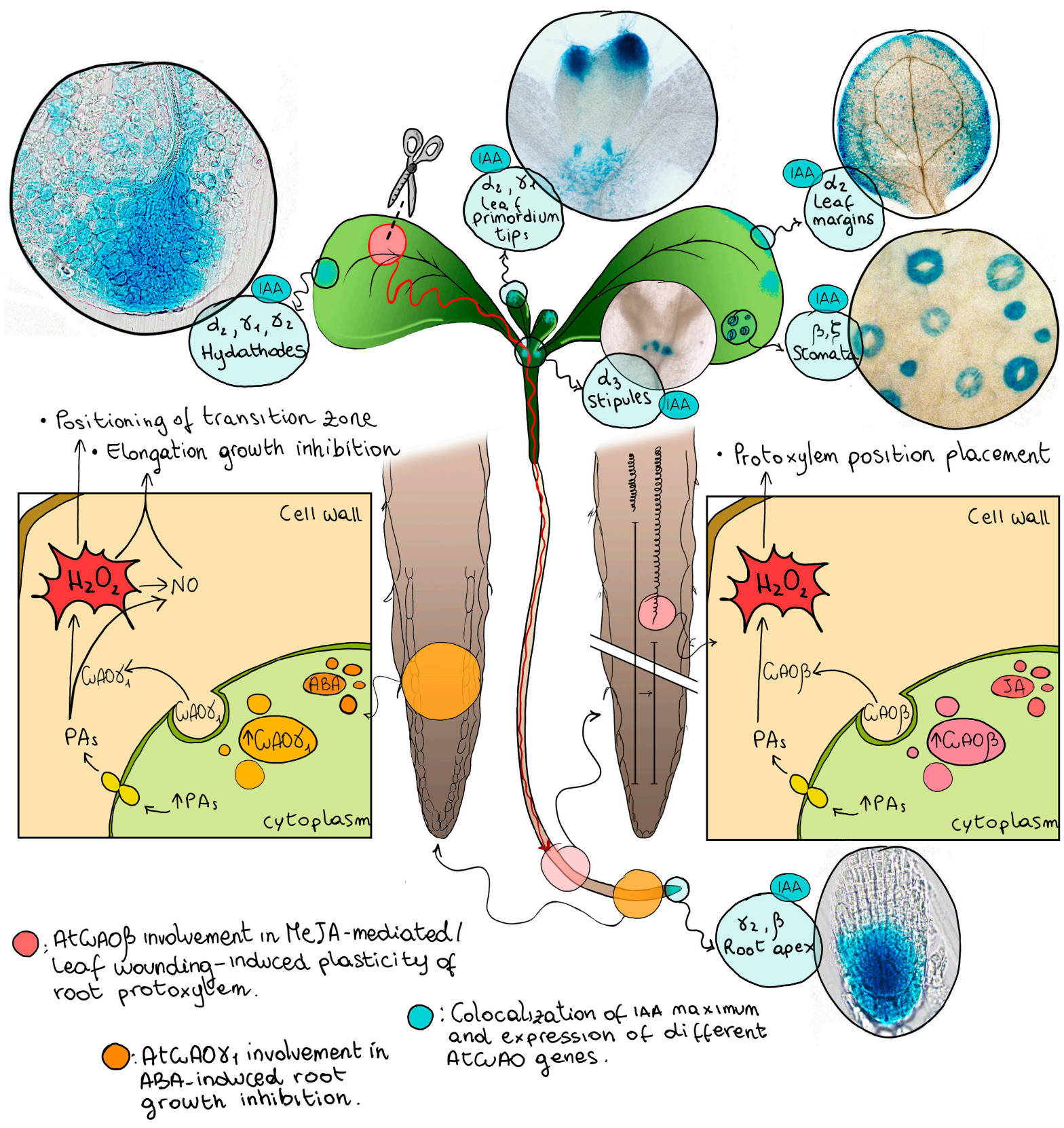

Figure 2. Involvement of AtCuAOs in long distance signaling and stress-induced phenotypic plasticity. Pink circles: schematic representation of AtCuAO $\beta$ involvement in MeJA-mediated/leaf wounding-induced plasticity of root protoxylem. Leaf-wounding triggers a long-distance leaf-to-root signaling leading to MeJA-mediated/AtCuAO $\beta$-driven early root protoxylem differentiation, highlighted by changes in root protoxylem position (i.e., the distance from the root apical meristem of the first protoxylem cell with fully developed secondary wall thickenings) [39,41]. Blu circles: co-localization of [IAA] maximum and the expression of $A t C u A O$ genes. Images associated to [IAA] maximum show GUS staining microscopy analysis of $A t C u A O \alpha 2 / \alpha 3 / \gamma 1 / \gamma 2 / \beta$ promoter::green fluorescent protein- $\beta$-glucuronidase fusion (prom- $A t C u A O:: G F P$ GUS) transgenic plants (unpublished images; transformed plants and experimental conditions have been described in $[38,39])$. Representative images for each tissue/organ are shown. Orange circles: A schematic representation of AtCuAOr 1 involvement in ABA-induced root growth inhibition by elongation growth regulation and transition zone positioning [48]. 
7. The AtCuAO $\beta$-Driven $\mathrm{H}_{2} \mathrm{O}_{2}$ Production Plays a Role in Stress-Induced/MeJA-Signaled Early Protoxylem Differentiation in the Root

A key role has been ascribed to $A t C u A O \beta$ in root xylem differentiation under both biotic stress, such as nematode infection, and abiotic stress as well as abiotic-simulated stress conditions, such as wounding and MeJA-signaled wound healing.

It has been reported that the cell wall-localized AtCuAO $\beta$ is expressed in correspondence of free-IAA maximum sites, such as root cap cells and protoxylem precursors at early stages of vascular tissue differentiation, and that its expression profile overlaps with lignin biosynthesis $[18,41]$. In particular, the $\mathrm{AtCuAO} \beta$ role in extra-cellular cross-linking of structural proteins or lignin precursors has been demonstrated during interactions with nematode parasites, correlating the $A t C u A O \beta$ profile expression with the re-differentiation process of root vascular tissues which occurs to contrast the effects of mechanical pressure caused by the nematode [74]. Moreover, it has been shown that $A t C u A O \beta$ expression is strongly induced by the wound-signal MeJA, especially in protoxylem at the transition, elongation and maturation zones [41]. Furthermore, it has been also reported that MeJA-treatment induces an early root protoxylem differentiation along with $\mathrm{H}_{2} \mathrm{O}_{2}$ accumulation in the position where the first cell with fully developed cell wall thickening is detected, while it does not occur in Atcuao $\beta$ loss-of-function mutants [41]. The absence of any detectable phenotypes in Atcuao $\beta$ mutants and the ineffectiveness of IAA in inducing AtCuAO $\beta$ expression [41] strongly suggest a peculiar role of this $A t C u A O$ in stress-induced protoxylem plasticity in root.

\section{AtCuAO $\beta$ Is Involved in Early Root Protoxylem Differentiation Induced by Leaf Wounding through Systemic Signaling}

A complex system for regulating growth and development is found in plants to deal with a plethora of external stimuli and continuous climate changes. Long-distance signaling is an essential leaf-root communication pathway, as it quickly and effectively triggers distal systemic response to environmental changes or mechanical damage perceived locally in specific plant areas [75]. When tissue damage occurs, the wound site become an easy way for pathogen infection and water loss and triggers both local responses, leading to wound healing $[57,76,77]$, and systemic responses, through a complex signaling pathways which spread the damage message from the injured tissues through the whole plant [75]. The sensing of wounding includes the production in the damaged area of early signaling molecules, among which the most important are ROS, glutamate and damage associated molecular patterns (DAMP), such as oligogalacturonides [76]. Glutamate triggers an increase of intracellular $\mathrm{Ca}^{2+}$ level through the activation of glutamate receptor-like proteins (GLRs), which are cation-permeable channels. Cytosolic $\mathrm{Ca}^{2+}$ increase is propagated as a wave to adjacent tissues leading to the systemic induction of JA biosynthesis at distal sites from the wound [78]. JA signaling in distal sites induces defense responses and the expression of stress-related genes among which $A O s$ [45].

In this context, the occurrence of a $\mathrm{H}_{2} \mathrm{O}_{2}$-mediated root phenotypic plasticity triggered through long-distance signaling pathways travelling from the wounded-leaf to the root has been reported. In detail, a specific $\mathrm{H}_{2} \mathrm{O}_{2}$ accumulation in root protoxylem has been detected soon after the injury followed by early root-protoxylem differentiation a few days later, with no observable changes in meristem size and whole root growth $[39,69]$. The effects of leaf wounding on $\mathrm{H}_{2} \mathrm{O}_{2}$-induced protoxylem differentiation in root along with the hormonal regulation features of $A t C u A O \beta$ expression, that is induced by MeJA and is un-responsive to IAA treatment, suggest that, under stress conditions caused by distal wounding, an extracellular $\mathrm{H}_{2} \mathrm{O}_{2}$ production may drive early root protoxylem differentiation independently from the auxin/cytokinin/T-Spm loop occurring in normalgrowth condition. The involvement of the $\mathrm{H}_{2} \mathrm{O}_{2}$ delivered from AtCuAO $\beta$-mediated PA oxidation in the early root protoxylem differentiation which occurs after leaf wounding [39], provides a link between an abiotic stress and a distal root phenotypic plasticity via systemic signaling (Figure 2). 
As a whole, since JA level increases in drought-stressed tissues and dehydration induces both the expression of many wound-related genes and modifications of xylem position, it is possible that leaf wounding activates dehydration signaling in roots leading to systemic event of phenotypic plasticity. In the specific case of the MeJA-mediated leaf wounding-induced early xylem differentiation in Arabidopsis root, the stress-signaling molecule $\mathrm{H}_{2} \mathrm{O}_{2}$ derives from the oxidation of PAs mediated by the apoplastic AtCuAO $\beta[39,41,61]$. In this context, root xylem plasticity could represent a rapid response directed to both increase water supply and remedy water loss consequent to the injury.

\section{AtCuAO $\gamma 1$ Is Involved in ABA-Associated Growth Responses}

The stress related-hormone ABA is well known to be involved in stomatal closure, maintenance of seed dormancy and rhizogenesis induced by drought. While the biosynthetic pathway of ABA is well known, its signaling mechanisms are complex and involve a large number of factors. A link between $\mathrm{AO}$ and nitric oxide (NO) in ABA-mediated stress responses, like the ABA-induced inhibition of germination and root growth, has been shown [48]. Plant growth and development, senescence, flowering, abiotic stress responses including stomatal closure and defense responses to pathogens are some of the various physiological processes in which both $\mathrm{AOs}$ and $\mathrm{NO}$ are involved, and these overlapping roles led to hypothesizes an interaction in their signaling pathways. In Arabidopsis seedlings, NO biosynthesis is induced by treatment with PAs through a pathway in which AOs are supposed to be directly or indirectly involved [79]. In details, insertional mutants deficient in AtCuAOr1 (Atcuaor1) have been shown to be defective in NO production and altered in both root growth and germination potential after treatment with ABA [80]. Consistently with a role of AtCuAO 1 in ABA-induced NO-mediated root growth inhibition, $A t C u A O \gamma 1$ expression is induced by ABA, especially in the root cortex of the root transition/elongation zone [21] (Figure 2). However, CuAOs do not directly produce NO, but may alter $\mathrm{NO}$ levels indirectly via $\mathrm{H}_{2} \mathrm{O}_{2}$ derived from $\mathrm{CuAO}$-mediated PA oxidation, that opens some calcium channels, supposed to act upstream of $\mathrm{NO}$ biosynthesis $[81,82]$.

\section{Conclusions}

This review updates knowledge on the physiological functions of plant $\mathrm{CuAOs}$ focusing on xylem phenotypic plasticity. In the first part of this review, a comprehensive analysis of subcellular localization, biochemical properties and hormone/stress-modulated expression profiles of $\mathrm{CuAOs}$ from different plant species is reported, with a special focus on AtCuAO tissue-specific expression. In the second part, the dual role of $\mathrm{CuAOs}$ on PA homeostasis and delivering of reactive/signaling compounds is argued. In particular, the main focus of this review concerns the role of $\mathrm{CuAOs}$ as component of local or systemic signaling pathways leading to developmentally regulated or stress-induced xylem phenotypic plasticity.

Auxin is a key regulator of vascular differentiation both in leaves, according to the leaf venation hypothesis, and roots, according to auxin/cytokinin/Thermo-Spm loop. The IAA-inducible expression of some members of the $A t C u A O$ family in zones where a freeauxin maximum has been reported, leads to hypothesize that this class of enzymes may contribute to developmentally regulated xylem differentiation by $\mathrm{H}_{2} \mathrm{O}_{2}$ production, both in leaves and roots. Furthermore, since $A t C u A O$ expression is also inducible by various stresses or stress-related hormones, it is tempting to speculate that their expression in free auxin production areas responsible for the xylem differentiation, could also be involved in events of xylem plasticity required for adaptation under stress conditions.

Indeed, it has been shown that the AtCuAO $\beta$-driven $\mathrm{H}_{2} \mathrm{O}_{2}$ production plays a role in stress-induced/MeJA-signaled early protoxylem differentiation in the root. Furthermore, AtCuAO $\beta$ is involved in long-distance leaf-to-root signaling pathways leading to early root protoxylem differentiation upon leaf wounding. Overall, this review highlights the $\mathrm{CuAO}$ role in stress-induced phenotypic plasticity, especially early root protoxylem differentiation. 
Author Contributions: Conceptualization, I.F., S.A.G., R.A.R.-P., R.A. and A.C.; design of the images, I.F. All authors have read and agreed to the published version of the manuscript.

Funding: This work was supported by the Italian “Ministero dell'Istruzione dell'Università e della Ricerca-MIUR" (PRIN 2017 project contract no. 2017ZBBYNC_002, CUP F84I19000730005 to R.A.); the Italian "Ministero dell'Istruzione dell'Università e della Ricerca-MIUR" (Grant of Excellence Departments MIUR-ARTICOLO 1, COMMI 314-337 LEGGE 232/2016; Italy; I.F., R.A. and A.C.); the Italian Università dell'Aquila-Department of Life, Health, and Environmental Sciences (Project "Ricerca d'Interesse d'Ateneo"-RIA 2019-2021; R.A.R.-P.).

Acknowledgments: This work was supported by Dipartimento Scienze, Università Roma Tre (Italy), Department of Health, Life and Environmental Science, Università dell'Aquila (Italy) and Institute of Plant Sciences, The Volcani Center (Israel).

Conflicts of Interest: The authors declare no conflict of interest.

\section{References}

1. Wuddineh, W.; Minocha, R.; Minocha, S.C. Polyamines in the Context of Metabolic Networks. Methods Mol. Biol. 2018, 1694, 1-23. [PubMed]

2. Alcázar, R.; Bueno, M.; Tiburcio, A.F. Polyamines: Small Amines with Large Effects on Plant Abiotic Stress Tolerance. Cells 2020, 9, 2373. [CrossRef] [PubMed]

3. Chen, D.; Shao, Q.; Yin, L.; Younis, A.; Zheng, B. Polyamine Function in Plants: Metabolism, Regulation on Development, and Roles in Abiotic Stress Responses. Front. Plant Sci. 2019, 9, 1945. [CrossRef]

4. Podlešáková, K.; Ugena, L.; Spíchal, L.; Doležal, K.; De Diego, N. Phytohormones and polyamines regulate plant stress responses by altering GABA pathway. New Biotechnol. 2019, 48, 53-65. [CrossRef] [PubMed]

5. Khajuria, A.; Sharma, N.; Bhardwaj, R.; Ohri, P. Emerging Role of Polyamines in Plant Stress Tolerance. Curr. Protein Pept. Sci. 2018, 19, 1114-1123. [CrossRef] [PubMed]

6. Handa, A.K.; Fatima, T.; Mattoo, A.K. Polyamines: Bio-Molecules with Diverse Functions in Plant and Human Health and Disease. Front. Chem. 2018, 6, 10. [CrossRef] [PubMed]

7. Fortes, A.M.; Agudelo-Romero, P. Polyamine Metabolism in Climacteric and Non-Climacteric Fruit Ripening. Methods Mol. Biol. 2018, 1694, 433-447.

8. Wang, W.; Paschalidis, K.; Feng, J.C.; Song, J.; Liu, J.H. Polyamine Catabolism in Plants: A Universal Process with Diverse Functions. Front. Plant Sci. 2019, 10, 561. [CrossRef]

9. Tavladoraki, P.; Cona, A.; Federico, R.; Tempera, G.; Viceconte, N.; Saccoccio, S.; Battaglia, V.; Toninello, A.; Agostinelli, E. Polyamine catabolism: Target for antiproliferative therapies in animals and stress tolerance strategies in plants. Amino Acids 2012, 42, 411-426. [CrossRef]

10. Tavladoraki, P.; Cona, A.; Angelini, R. Copper-containing amine oxidases and FAD-dependent polyamine oxidases are key players in plant tissue differentiation and organ development. Front. Plant Sci. 2016, 7, 824. [CrossRef]

11. Moschou, P.N.; Wu, J.; Cona, A.; Tavladoraki, P.; Angelini, R.; Roubelakis-Angelakis, K.A. The polyamines and their catabolic products are significant players in the turnover of nitrogenous molecules in plants. J. Exp. Bot. 2012, 63, 5003-5015. [CrossRef]

12. Angelini, R.; Cona, A.; Federico, R.; Fincato, P.; Tavladoraki, P.; Tisi, A. Plant amine oxidases "on the move": An update. Plant Physiol. Biochem. 2010, 48, 560-564. [CrossRef]

13. Cona, A.; Rea, G.; Angelini, R.; Federico, R.; Tavladoraki, P. Functions of amine oxidases in plant development and defence. Trends Plant Sci. 2006, 11, 80-88. [CrossRef] [PubMed]

14. Federico, R.; Angelini, R. Polyamine catabolism in plants. In Biochemistry and Physiology of Polyamines in Plants, 1st ed.; Slocum, R.D., Flores, H.E., Eds.; CRC Press: Boca Raton, FL, USA, 1991; pp. 41-56.

15. Šebela, M.; Radová, A.; Angelini, R.; Tavladoraki, P.; Frébort, I.; Peč, P. FAD-containing polyamine oxidases: A timely challenge for researchers in biochemistry and physiology of plants. Plant Sci. 2001, 160, 197-207. [CrossRef]

16. Groß, F.; Rudolf, E.E.; Thiele, B.; Durner, J.; Astier, J. Copper amine oxidase 8 regulates arginine-dependent nitric oxide production in Arabidopsis thaliana. J. Exp. Bot. 2017, 68, 2149-2162. [CrossRef] [PubMed]

17. Planas-Portell, J.; Gallart, M.; Tiburcio, A.F.; Altabella, T. Copper containing amine oxidases contribute to terminal polyamine oxidation in peroxisomes and apoplast of Arabidopsis thaliana. BMC Plant Biol. 2013, 13, 109. [CrossRef]

18. Møller, S.G.; McPherson, M.J. Developmental expression and biochemical analysis of the Arabidopsis atao1 gene encoding an $\mathrm{H}_{2} \mathrm{O}_{2}$-generating diamine oxidase. Plant J. 1998, 13, 781-791. [CrossRef] [PubMed]

19. Naconsie, M.; Kato, K.; Shoji, T.; Hashimoto, T. Molecular evolution of N-methylputrescine oxidase in tobacco. Plant Cell Physiol. 2014, 55, 436-444. [CrossRef]

20. Qu, Y.; An, Z.; Zhuang, B.; Jing, W.; Zhang, Q.; Zhang, W. Copper amine oxidase and phospholipase D act independently in abscisic acid (ABA)-induced stomatal closure in Vicia faba and Arabidopsis. J. Plant Res. 2014, 127, 533-544. [CrossRef] 
21. Fraudentali, I.; Ghuge, S.A.; Carucci, A.; Tavladoraki, P.; Angelini, R.; Rodrigues-Pousada, R.A.; Cona, A. Developmental, hormone- and stress-modulated expression profiles of four members of the Arabidopsis copper-amine oxidase gene family. Plant Physiol. Biochem. 2020, 147, 141-160. [CrossRef]

22. Wang, W.; Wu, H.; Liu, J.H. Genome-wide identification and expression profiling of copper-containing amine oxidase genes in sweet orange (Citrus sinensis). Tree Genet. Genomes 2017, 13, 31. [CrossRef]

23. Bharalee, R.; Gupta, S.; Bandyopadhyay, T.; Gohain, B.; Agarwala, N.; Kalita, C.M.; Das, S. Molecular cloning, expression and computational analysis of a water stress inducible copper-containing amine oxidase gene $(\mathrm{CuAO})$ from tea plant [Camellia sinensis (L.) O. Kuntze]. Afr. J. Biotechnol. 2012, 11, 15547-15555.

24. Boudart, G.; Jamet, E.; Rossignol, M.; Lafitte, C.; Borderies, G.; Jauneau, A.; Esquerré-Tugayé, M.T.; Pont-Lezica, R. Cell wall proteins in apoplastic fluids of Arabidopsis thaliana rosettes: Identification by mass spectrometry and bioinformatics. Proteomics 2005, 5, 212-221. [CrossRef] [PubMed]

25. Zarei, A.; Trobacher, C.P.; Cooke, A.R.; Meyers, A.J.; Hall, J.C.; Shelp, B.J. Apple fruit copper amine oxidase isoforms: Peroxisomal MdAO1 prefers diamines as substrates, whereas extracellular MdAO2 exclusively utilizes monoamines. Plant Cell Physiol. 2015, 56, 137-147. [CrossRef] [PubMed]

26. Laurenzi, M.; Tipping, A.J.; Marcus, S.E.; Knox, J.P.; Federico, R.; Angelini, R.; McPherson, M.J. Analysis of the distribution of copper amine oxidase in cell walls of legume seedlings. Planta 2001, 214, 37-45. [CrossRef] [PubMed]

27. Padiglia, A.; Medda, R.; Scanu, T.; Longu, S.; Rossi, A.; Floris, G. Structure and nucleotide sequence of Euphorbia characias copper/TPQ-containing amine oxidase gene. J. Protein Chem. 2002, 21, 435-441. [CrossRef]

28. Rossi, A.; Petruzzelli, R.; Agrò, A.F. cDNA-derived amino-acid sequence of lentil seedlings' amine oxidase. FEBS Lett. 1992, 301, 253-257. [CrossRef]

29. An, Z.; Jing, W.; Liu, Y.; Zhang, W. Hydrogen peroxide generated by copper amine oxidase is involved in abscisic acid-induced stomatal closure in Vicia faba. J. Exp. Bot. 2008, 59, 815-825. [CrossRef]

30. Fukao, Y.; Hayashi, M.; Hara-Nishimura, I.; Nishimura, M. Novel glyoxysomal protein kinase, GPK1, identified by proteomic analysis of glyoxysomes in etiolated cotyledons of Arabidopsis thaliana. Plant Cell Physiol. 2003, 44, 1002-1012. [CrossRef]

31. Carter, C.; Pan, S.; Zouhar, J.; Avila, E.L.; Girke, T.; Raikhel, N.V. The vegetative vacuole proteome of Arabidopsis thaliana reveals predicted and unexpected proteins. Plant Cell 2004, 16, 3285-3303. [CrossRef]

32. Pietrangeli, P.; Federico, R.; Mondovì, B.; Morpurgo, L. Substrate specificity of copper-containing plant amine oxidases. J. Inorg. Biochem. 2007, 101, 997-1004. [CrossRef] [PubMed]

33. Padiglia, A.; Floris, G.; Longu, S.; Schininà, M.E.; Pedersen, J.Z.; Finazzi Agrò, A.; De Angelis, F.; Medda, R. Inhibition of lentil copper/TPQ amine oxidase by the mechanism-based inhibitor derived from tyramine. Biol. Chem. 2004, 385, 323-329. [CrossRef] [PubMed]

34. Katoh, A.; Shoji, T.; Hashimoto, T. Molecular cloning of N-Methyl putrescine oxidase from tobacco. Plant Cell Physiol. 2007, 48, 550-554. [CrossRef] [PubMed]

35. Marina, M.; Maiale, S.J.; Rossi, F.R.; Romero, M.F.; Rivas, E.I.; Gárriz, A.; Ruiz, O.A.; Pieckenstain, F.L. Apoplastic polyamine oxidation plays different roles in local responses of tobacco to infection by the necrotrophic fungus Sclerotinia sclerotiorum and the biotrophic bacterium Pseudomonas viridiflava. Plant Physiol. 2008, 147, 2164-2178. [CrossRef] [PubMed]

36. Šebela, M.; Brauner, F.; Radová, A.; Jacobsen, S.; Havlis, J.; Galuszka, P.; Pec, P. Characterisation of a homogeneous plant aminoaldehyde dehydrogenase. Biochim. Biophys. Acta 2000, 1480, 329-341. [CrossRef]

37. Petřivalský, M.; Brauner, F.; Luhová, L.; Gagneul, D.; Šebela, M. Aminoaldehyde dehydrogenase activity during wound healing of mechanically injured pea seedlings. J. Plant Physiol. 2007, 164, 1410-1418. [CrossRef]

38. Ghuge, S.A.; Carucci, A.; Rodrigues-Pousada, R.A.; Tisi, A.; Franchi, S.; Tavladoraki, P.; Angelini, R.; Cona, A. The MeJA-inducible copper amine oxidase AtAO1 is expressed in xylem tissue and guard cells. Plant Signal. Behav. 2015, 10, e1073872. [CrossRef]

39. Fraudentali, I.; Rodrigues-Pousada, R.A.; Tavladoraki, P.; Angelini, R.; Cona, A. Leaf-Wounding Long-Distance Signaling Targets AtCuAO $\beta$ Leading to Root Phenotypic Plasticity. Plants 2020, 9, 249. [CrossRef]

40. Qu, Y.; Wang, Q.; Guo, J.; Wang, P.; Song, P.; Jia, Q.; Zhang, X.; Kudla, J.; Zhang, W.; Zhang, Q. Peroxisomal CuAO $\zeta$ and its product $\mathrm{H}_{2} \mathrm{O}_{2}$ regulate the distribution of auxin and IBA-dependent lateral root development in Arabidopsis. J. Exp. Bot. 2017, 68, 4851-4867. [CrossRef]

41. Ghuge, S.A.; Carucci, A.; Rodrigues-Pousada, R.A.; Tisi, A.; Franchi, S.; Tavladoraki, P.; Angelini, R.; Cona, A. The apoplastic copper AMINE OXIDASE1 mediates jasmonic acid-induced protoxylem differentiation in Arabidopsis roots. Plant Physiol. 2015, 168, 690-707. [CrossRef]

42. Fraudentali, I.; Ghuge, S.A.; Carucci, A.; Tavladoraki, P.; Angelini, R.; Cona, A.; Rodrigues-Pousada, R.A. The Copper Amine Oxidase Atcuao $\delta$ participates in Abscisic Acid-Induced Stomatal Closure in Arabidopsis. Plants 2019, 8, 183. [CrossRef] [PubMed]

43. Walters, D.; Cowley, T.; Mitchell, A. Methyl jasmonate alters polyamine metabolism and induces systemic protection against powdery mildew infection in barley seedlings. J. Exp. Bot. 2002, 53, 747-756. [CrossRef]

44. Biondi, S.; Scaramagli, S.; Capitani, F.; Altamura, M.M.; Torrigiani, P. Methyl jasmonate upregulates biosynthetic gene expression, oxidation and conjugation of polyamines, and inhibits shoot formation in tobacco thin layers. J. Exp. Bot. 2001, 52, 231-242. [CrossRef]

45. Rea, G.; Metoui, O.; Infantino, A.; Federico, R.; Angelini, R. Copper amine oxidase expression in defense responses to wounding and Ascochyta rabiei invasion. Plant Physiol. 2002, 128, 865-875. [CrossRef] [PubMed] 
46. Moschou, P.N.; Paschalidis, K.A.; Delis, I.D.; Andriopoulou, A.H.; Lagiotis, G.D.; Yakoumakis, D.I.; Roubelakis-Angelakis, K.A. Spermidine exodus and oxidation in the apoplast induced by abiotic stress is responsible for $\mathrm{H}_{2} \mathrm{O}_{2}$ signatures that direct tolerance responses in tobacco. Plant Cell. 2008, 20, 1708-1724. [CrossRef]

47. Xing, S.G.; Jun, Y.B.; Hau, Z.W.; Liang, L.Y. Higher accumulation of gamma-aminobutyric acid induced by salt stress through stimulating the activity of diamine oxidases in Glycine max (L.) Merr. roots. Plant Physiol. Biochem. 2007, 45, 560-566. [CrossRef] [PubMed]

48. Wimalasekera, R.; Villar, C.; Begum, T.; Scherer, G.F.E. COPPER AMINE OXIDASE1 (CuAO1) of Arabidopsis thaliana contributes to abscisic acid- and polyamine-induced nitric oxide biosynthesis and abscisic acid signal transduction. Mol. Plant. 2011, 4, 663-678. [CrossRef] [PubMed]

49. Flores, T.; Todd, C.D.; Tovar-Mendez, A.; Dhanoa, P.K.; Correa-Aragunde, N.; Hoyos, M.E.; Brownfield, D.M.; Mullen, R.T.; Lamattina, L.; Polacco, J.C. Arginase-negative mutants of Arabidopsis exhibit increased nitric oxide signaling in root development. Plant Physiol. 2008, 147, 1936-1946. [CrossRef] [PubMed]

50. Torrigiani, P.; Serafini-Fracassini, D.; Fara, A. Diamine Oxidase Activity in Different Physiological Stages of Helianthus tuberosus Tuber. Plant Physiol. 1989, 89, 69-73. [CrossRef]

51. Gemperlová, L.; Eder, J.; Cvikrová, M. Polyamine metabolism during the growth cycle of tobacco BY-2 cells. Plant Physiol. Biochem. 2005, 43, 375-381. [CrossRef]

52. Paschalidis, K.A.; Roubelakis-Angelakis, K.A. Sites and regulation of polyamine catabolism in the tobacco plant. Correlations with cell division/expansion, cell cycle progression, and vascular development. Plant Physiol. 2005, 138, 2174-2184. [CrossRef]

53. Alharbi, B.; Hunt, J.D.; Dimitrova, S.; Spadafora, N.D.; Cort, A.P.; Colombo, D.; Müller, C.T.; Ghuge, S.A.; Davoli, D.; Cona, A.; et al. Mutation of Arabidopsis copper-containing amine oxidase gene AtCuAO $\delta$ alters polyamines, reduces gibberellin content and affects development. Int. J. Mol. Sci. 2020, 21, 7789. [CrossRef]

54. Hatmi, S.; Villaume, S.; Trotel-Aziz, P.; Barka, E.A.; Clément, C.; Aziz, A. Osmotic Stress and ABA Affect Immune Response and Susceptibility of Grapevine Berries to Gray Mold by Priming Polyamine Accumulation. Front. Plant Sci. 2018, 9, 1010. [CrossRef]

55. Rodríguez, A.A.; Maiale, S.J.; Menéndez, A.B.; Ruiz, O.A. Polyamine oxidase activity contributes to sustain maize leaf elongation under saline stress. J. Exp. Bot. 2009, 60, 4249-4262. [CrossRef] [PubMed]

56. Rea, G.; de Pinto, M.C.; Tavazza, R.; Biondi, S.; Gobbi, V.; Ferrante, P.; de Gara, L.; Federico, R.; Angelini, R.; Tavladoraki, P. Ectopic expression of maize polyamine oxidase and pea copper amine oxidase in the cell wall of tobacco plants. Plant Physiol. 2004, 134, 1414-1426. [CrossRef] [PubMed]

57. Cona, A.; Tisi, A.; Ghuge, S.A.; Franchi, S.; De Lorenzo, G.; Angelini, R. Wound healing response and xylem differentiation in tobacco plants over-expressing a fungal endopolygalacturonase is mediated by copper amine oxidase activity. Plant Physiol. Biochem. 2014, 82, 54-65. [CrossRef]

58. Huang, A.X.; Wang, Y.S.; She, X.P.; Mu, J.; Zhao, J.L. Copper amine oxidase-catalysed hydrogen peroxide involves production of nitric oxide in darkness-induced stomatal closure in broad bean. Funct. Plant Biol. 2015, 42, 1057-1067. [CrossRef]

59. Liu, C.; Atanasov, K.E.; Arafaty, N.; Murillo, E.; Tiburcio, A.F.; Zeier, J.; Alcázar, R. Putrescine elicits ROS-dependent activation of the salicylic acid pathway in Arabidopsis thaliana. Plant Cell Environ. 2020, 43, 2755-2768. [CrossRef] [PubMed]

60. Tisi, A.; Federico, R.; Moreno, S.; Lucretti, S.; Moschou, P.N.; Roubelakis-Angelakis, K.A.; Angelini, R.; Cona, A. Perturbation of polyamine catabolism can strongly affect root development and xylem differentiation. Plant Physiol. 2011, 157, 200-215. [CrossRef] [PubMed]

61. Ghuge, S.A.; Tisi, A.; Carucci, A.; Rodrigues-Pousada, R.A.; Franchi, S.; Tavladoraki, P.; Angelini, R.; Cona, A. Cell wall amine oxidases: New players in root xylem differentiation under stress conditions. Plants 2015, 4, 489-504. [CrossRef]

62. Cui, X.; Ge, C.; Wang, R.; Wang, H.; Chen, W.; Fu, Z.; Jiang, X.; Li, J.; Wang, Y. The BUD2 mutation affects plant architecture through altering cytokinin and auxin responses in Arabidopsis. Cell Res. 2010, 20, 576-586. [CrossRef] [PubMed]

63. Baima, S.; Forte, V.; Possenti, M.; Peñalosa, A.; Leoni, G.; Salvi, S.; Felici, B.; Ruberti, I.; Morell, G. Negative feedback regulation of auxin signaling by ATHB8/ACL5 BUD2 transcription module. Mol. Plant. 2014, 7, 1006-1025. [CrossRef] [PubMed]

64. Salvi, E.; Rutten, J.P.; Di Mambro, R.; Polverari, L.; Licursi, V.; Negri, R.; Dello Ioio, R.; Sabatini, S.; Ten Tusscher, K. A SelfOrganized PLT/Auxin/ARR-B Network Controls the Dynamics of Root Zonation Development in Arabidopsis thaliana. Dev. Cell 2020, 53, 431-443.e23. [CrossRef] [PubMed]

65. Bennett, T. Root Development: A Go-Faster Stripe and Spoilers. Dev. Cell 2020, 53, 372-374. [CrossRef] [PubMed]

66. Rost, T.L.; Baum, S. On the correlation of primary root length, meristem size and protoxylem tracheary element position in pea seedlings. Am. J. Bot. 1988, 75, 414-424. [CrossRef]

67. Tsukagoshi, H.; Busch, W.; Benfey, P.N. Transcriptional regulation of ROS controls transition from proliferation to differentiation in the root. Cell 2010, 143, 606-616. [CrossRef]

68. Zhou, X.; Xiang, Y.; Li, C.; Yu, G. Modulatory Role of Reactive Oxygen Species in Root Development in Model Plant of Arabidopsis thaliana. Front. Plant Sci. 2020, 11, 485932. [CrossRef]

69. Fraudentali, I.; Rodrigues-Pousada, R.A.; Volpini, A.; Tavladoraki, P.; Angelini, R.; Cona, A. Stress-Triggered Long-Distance Communication Leads to Phenotypic Plasticity: The Case of the Early Root Protoxylem Maturation Induced by Leaf Wounding in Arabidopsis. Plants 2018, 7, 107. [CrossRef]

70. Aloni, R. The induction of vascular tissues by auxin and cytokinin. In Plant Hormones: Physiology, Biochemistry and Molecular Biology, 2nd ed.; Davies, P.J., Ed.; Kluwer Academic Publishers: Dordrecht, The Netherlands, 1995; pp. 531-546. 
71. Aloni, R. Foliar and axial aspects of vascular differentiation: Hypotheses and evidence. J. Plant Growth Regul. 2001, 20, 22-34. [CrossRef]

72. Aloni, R.; Schwalm, K.; Langhans, M.; Ullrich, C.I. Gradual shifts in sites of free-auxin production during leaf-primordium development and their role in vascular differentiation and leaf morphogenesis in Arabidopsis. Planta 2003, 216, 841-853. [CrossRef]

73. Jacobs, J.; Roe, J.L. SKS6, a multicopper oxidase-like gene, participates in cotyledon vascular patterning during Arabidopsis thaliana development. Planta 2005, 222, 652-666. [CrossRef] [PubMed]

74. Møller, S.G.; Urwin, P.E.; Atkinson, H.J.; McPherson, M.J. Nematode induced expression of atao1, a gene encoding an extracellular diamine oxidase associated with developing vascular tissue. Physiol. Mol. Plant Pathol. 1998, 53, 73-79. [CrossRef]

75. Hilleary, R.; Gilroy, S. Systemic signaling in response to wounding and pathogens. Curr. Opin. Plant Biol. 2018, 43, 57-62. [CrossRef]

76. Savatin, D.V.; Gramegna, G.; Modesti, V.; Cervone, F. Wounding in the plant tissue: The defense of a dangerous passage. Front. Plant Sci. 2014, 5, 470. [CrossRef] [PubMed]

77. Heyman, J.; Canher, B.; Bisht, A.; Christiaens, F.; De Veylder, L. Emerging role of the plant ERF transcription factors in coordinating wound defense responses and repair. J Cell Sci. 2018, 29, 131-132. [CrossRef]

78. Lee, H.J.; Park, J.S.; Shin, S.Y.; Kim, S.G.; Lee, G.; Kim, H.S.; Jeon, J.H.; Cho, H.S. Submergence deactivates wound-induced plant defence against herbivores. Commun. Biol. 2020, 3, 651. [CrossRef]

79. Tun, N.N.; Santa-Catarina, C.; Begum, T.; Silveira, V.; Handro, W.; Floh, I.S.; Scherer, G.F.E. Polyamines induce rapid biosynthesis of nitric oxide (NO) in Arabidopsis thaliana seedlings. Plant Cell Physiol. 2006, 47, 346-354. [CrossRef]

80. Wimalasekera, R.; Tebartz, F.; Scherer, G.F.E. Polyamines, polyamines oxidases and nitric oxide in development, abiotic and biotic stresses. Plant Sci. 2011, 181, 593-603. [CrossRef]

81. Kwak, J.M.; Mori, I.C.; Pei, Z.M.; Leonhardt, N.; Torres, M.A.; Dangl, J.L.; Bloom, R.E.; Bodde, S.; Jones, J.D.G.; Schroeder, J.I. NADPH oxidase AtrbohD and AtrbohF genes function in ROS-dependent ABA signaling in Arabidopsis. EMBO J. 2003, 22, 2623-2633. [CrossRef]

82. Courtois, C.; Besson, A.; Dahan, J.; Bourque, S.; Dobrowolska, G.; Pugin, A.; Wendehenne, D. Nitric oxide signaling in plants: Interplays with $\mathrm{Ca}^{2+}$ and protein kinases. J. Exp. Bot. 2008, 59, 155-163. [CrossRef] 